\title{
Landslide Disaster Risk Strategy: Lesson Learned from the Community in the Northwest Part of Bromo Volcano Flank
}

\author{
Shofiyatul Azmi ${ }^{1}$, Heni Masruroh ${ }^{2}$, Indria Kristiawan ${ }^{2}$, Umi Afdah ${ }^{3}$ \\ ${ }^{1,3.4}$ Wisnuwardhana University, East Java, Indonesia \\ ${ }^{2}$ Malang State University, East Java, Indonesia \\ heni.masruroh.fis@um.ac.id
}

\begin{abstract}
This research was conducted on the western flank of Mount Bromo, precisely on the upper slopes of Taji Village with a population of 1,286. Communities have intensively exploited land resources to meet their daily needs. Based on the physical condition, this area is rather not appropriate for living. In the other hand, the community had been survived to live in harmony with high potential erosion prone area. The purpose of this study is to elaborate disaster risk reduction strategies in the northwest part of Bromo Volcano Flank. The research method used is in-depth interviews, questionnaires and focus group discussions. We found an interesting fact that the local people are very aware of the environment in which they live. The community has several strategies for landslide risk reduction based on their experience and knowledge. The developed strategy still considers environmental, economic and social aspects. Even the community has developed its territory as a tourist destination in Malang Regency by offering natural beauty. Strategies developed by the community The win-win solution between conserving soil from landslides and preserving economic income is an interesting lesson for others outside the study area
\end{abstract}

Keywords- Landslide, Risk, Strategy, lesson Learned, Community.

\section{INTRODUCTION}

Geographically, most of Indonesia is located in areas prone to landslides. The flank of Mount Bromo in the southwest, which is located in East Java Province, is one of the areas prone to landslides. The main causes of landslides are geomorphological, geological, climatological and hydrological conditions. In general, the physical condition of the area will affect people's lives and livelihoods [1]. The extreme physical conditions of the region can affect the shape of the land surface characteristics [2] [3] [4].

The occurrence of landslides is one of the geomorphological processes that occur due to the extreme physical conditions of the area. Landslides in an area will affect human activities [5] [6] [7]. Landslide is one of the most common hydrometerological disasters in Indonesia.
Most landslides occur in hilly areas and at the peak of the rainy season.

The area which is located on the southwest wing of the slopes of Mount Bromo has a high vulnerability to landslides. This area is precisely in Taji Village which is also a village located in the Bromo Tengger Semeru area. This area has a high vulnerability to landslides [8] [9]. This is because this area has a rough surface and the surface material is the result of depositional material from Mount Bromo. There have been many landslides, both translational and rotational types that have occurred in this area.

As humans who live in landslide-prone areas have challenges to survive, so humans who live in this area must be able to. Humans who live in landslide areas must be able to adapt. Humans in the landslide process can trigger landslides, but on the other hand humans also have the ability to reduce the risk of landslides through their strategies. So far, the reduction of landslide potential has been mostly carried out with a physical approach to the area, namely vegetative and mechanical conservation [10] [11].

Conservation efforts are really needed in order to reduce landslide risk, but landslide risk reduction can also be done on a community basis. People who live in Taji Village have a strategy for community-based landslide risk reduction. The disaster risk reduction strategy carried out by the community is also an effort to maintain environmental sustainability, maintain sustainable economic income and strengthen social relations between communities. This paper will explain the communitybased strategy for reducing the risk of landslides in the southwest wing of Mount Bromo.

\section{RESEARCH METHOD}

The location of the study was carried out in the southwest wing of Mount Bromo, precisely in Taji Village. This area has a very rough surface characteristic of hills. The composition of the surface material is in the form of material deposition from Mount Bromo. In several parts of the slopes in this area, many landslides, both translational and rotational landslides are found (Fig. 
1). Data collection in this study was carried out by snowballing in depth interviews with people who live in areas most prone to landslides, FGD with representatives of the Community-Based Disaster Preparedness (SIBAT) management in Taji Village, totaling 3 people, 10 village administrators and each head of the RT from The hamlets of Krajan and Umbut Legi are 9 people. The main focus in data collection is on community strategies in efforts to reduce disaster risk. In this study, observations were also made in areas prone to landslides. depth interviews. Data from interviews, FGDs, and observations were tabulated and data reduction. The results of this study are a landslide risk reduction strategy adopted by the people of Taji Village, which is located northwest flank of Bromo Volcano. The strategy developed by the Taji Village community is based on the experience and local wisdom of the community. The developed strategy considers social, economic and environmental aspects.
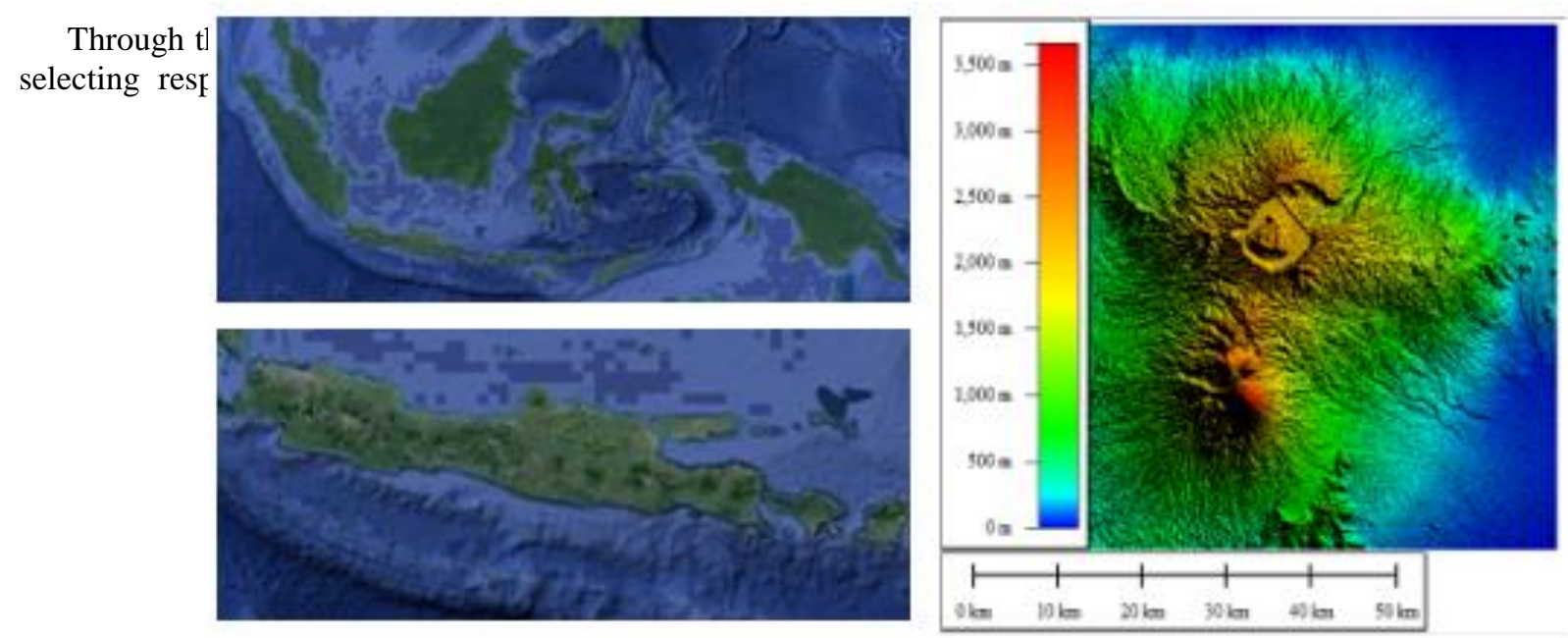

Figure 1: Research Area

\section{FINDINGS AND DISCUSSION}

\section{Physical Characteristics of the Area and Analysis of Landslides in the Research Area}

The physical characteristics of the area and the potential for landslides have an interrelated relationship. The physical characteristics of the area can be identified through morphological conditions, surface materials, and geomorphological processes [12]. To identify morphology, it can be done through topographic position index analysis [13] [14]. The southwest flank of the Bromo volcano has a high potential for landslides. Based on the physical analysis of the area in the form of morphological analysis with a topographical position approach, it shows that most of the morphology of this area is hilly consisting of hilltops $(0.6 \%)$, upper slopes $(10 \%)$, middle slopes $(9.49 \%)$, lower slopes $(39.36 \%)$, and bad channel (40.49\%).

Morphological conditions affect the movement of the material. The flat morphology in the form of hilltops and channel bad has a low vulnerability to material movement because the flat morphology does not have the power to move the material. This is different from the morphology of the upper, middle and foot slopes which have a slope, so they have energy in moving landslide material.

The upper slope has the most energy in moving the material compared to the middle slope and foot slope. In the research area, between the top of the hill and the upper slope, many soil cracks were found, which is an early indicator of material movement.

The research area is one of the villages located in the Bromo Tengger Semeru area. Overall this area is a volcanic area with geological formations consisting of the results of the activity of the young quarter volcano and the old quarter volcano. The surface rock in this area consists of andesite, basalt and volcanic tuff. Soil physics analysis has been carried out in three measurement plots. Based on laboratory results in three plots, the proportion of dust was highest compared to sand and clay, namely in plot 1 $48.10 \%$, plot $264.71 \%$ and plot $331.34 \%$. The texture of the soil which tends to be dusty causes the soil to be slippery, so if the soil is exposed to water it will be easily dispersed.

The type of land use in the research area is agriculture with woody plant species such as bamboo and horticultural crops such as cabbage, carrots, coffee, apples, chilies, spring onions, and tomatoes. The crop planting system in the research area uses an intercropping system with a terracing technique. This planting system is part of the community's efforts to reduce the risk of landslides. In addition, the planting system with intercropping is the main source of income for the community because through intercropping with various types of horticultural crops, the community has different times for harvesting. 

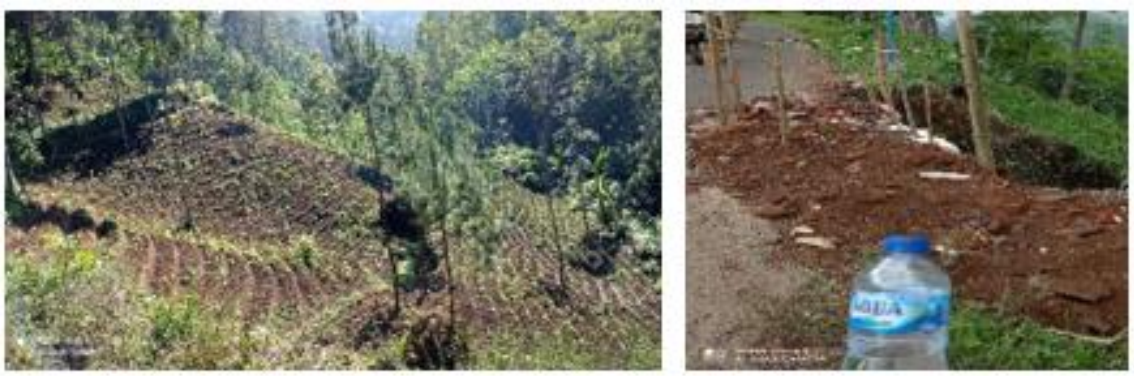

Figure 2: Landslide in the Research Area

Landslides in the study area occur very intensively, both translational and rotational. Landslides that occurred in the study area were caused by the morphological conditions of the research area in the form of hills and thick surface material deposited from Mount Bromo. This can be identified through scarp landslides that have occurred. Landslides that occur in the study area have their own characteristics. Rotational landslides occur on gentler slopes than translational landslides. The community has cultivated the land used for rotational avalanches for horticultural agriculture, while the land used for translational landslide is not used by the community because it is associated with roads (Fig. 2).

\section{Optimizing Research Areas to Become Tourist Attractions}

As a village located in the Bromo Tengger Semeru (BTS) area, the formation of this area is strongly influenced by geological and geomorphological processes. Morphochronology of this area in addition to causing this area prone to landslides, this area also gives the appearance of natural beauty. Communities in the research area are able to optimize environmental management in order to survive. One of the optimization of environmental management that has an impact on people's income is that the community processes its territory for tourism. Currently, the tourism branding used by the community in developing a tourist village district is the Thousand Coban Village.

In the research area, there are more than 5 waterfalls/trials that have been developed by the community. The development of tourist villages as part of an effort to reduce the risk of landslides has had an impact on people's incomes to be able to survive even in landslide-prone areas. For the community, the threat of landslides is not a barrier to village development. The existence of Coban has existed since the community has not carried out intensive processing. Taji Village has an altitude of 1,200 meters above sea level and is the highest place in Malang Regency, so that tourist visitors can enjoy the beauty of the city and Malang Regency. Through the development of tourist attractions 1000 Coban can provide income for the community.

The development of a tourist village at the research site is also supported by the existence of coffee plants which are actually used by the community as landslide conservation. However, with the existence of coffee cultivation, this makes it a coffee tourist destination. The local community of Taji Village grows coffee not only as part of conservation efforts, but the coffee grown by the local community of Taji Village has become an iconic Taji coffee. Based on information from the community, Kopi Taji has premium quality with the Arabica type (Interview, 2020). Coffee cultivation carried out by the local community of Taji Village supports Taji Village as a Tourism Village. Based on observations, it shows that the community is able to live in harmony with threats and the community is able to seize opportunities from physiographic conditions to be developed into a tourist village.

\section{Environmental Management with Vegetative Conservation Approach}

Another strategy carried out by the community in the research area as an effort to reduce the risk of landslides is to cultivate agricultural land with vegetative conservation. Land cultivation developed by the community is closely related to livelihoods. Most of the communities in the research area have cultivated agroforestry systems by mixing woody plants with horticultural crops. The arrangement of the types of plants used is based on the time of harvest.

The application of the agroforestry system in the study area has a positive impact on reducing soil material movement. Through the agroforestry system, there are various types of root systems and leaf canopies that affect the infiltration process. Differences in plant species also affect the leaf canopy which can reduce hydropower hitting the soil [15] [16]. This includes influencing the infiltration process, run off, and soil mass loads. For the most part, land without vegetation has greater runoff than infiltration [17]. This affects the process of moving soil material during the rainy season. Agroforestry is an annual forest management system combined with an agricultural system. Thus, agroforestry plantations can be in the form of forest crops (woody plants) and agricultural crops including horticulture and secondary crops. Mixed gardens are agroforestry applied in the study area.

Through the application of planting systems with agroforestry techniques, it does not only have an impact on reducing the risk of landslides. The application of the agroforestry system has a socio-economic impact on the community. Through the implementation of this planting system, it is able to provide annual, monthly, weekly and daily income for the community so that the existence of 
agricultural land in the research area is a very important part to support people's lives. In the division of plant species, the community divides the types of plants into seasonal plants, annual plants, horticultural plants and woody plants.

\section{Community Based Disaster Risk Reduction.}

Communities have a role in environmental management for disaster risk reduction [18]. Communities in the study area have a high threat of landslides. Disaster management will continue as a consequence of the geographical conditions of the region, so efforts are needed to reduce disaster risk. In the research area, the community has made efforts to reduce disaster risk, both structural and non-structural. The community realizes that one of the efforts that can be done in disaster risk reduction is public awareness and knowledge about disasters. The people of Taji Village are very aware that their environment has the potential for landslides, so that currently the people of Taji Village have formed a community that has a focus on disaster risk reduction efforts. This community is called SIBAT, which is the Community-Based Disaster Preparedness Community.

Community-based disaster risk reduction carried out by the community through SIBAT can be followed by people who are willing to help time, energy, and thoughts in disaster emergency preparedness and response efforts. There are several tasks of SIBAT, namely 1) carrying out capacity building and community organizing efforts; 2) carry out socialization and public awareness about hazards, vulnerabilities and risks; 3 ) conduct participatory landslide mapping; 4) provide training and counseling to the community regarding preparedness; 5) raise public awareness to participate in planning, implementation, monitoring, evaluation, and environmental sustainability.

Based on the focus group discussion with the management of Taji Village, representatives of each RT, and the people who live in landslide-prone areas, it is shown that the existence of SIBAT is very helpful regarding disaster management in Taji Village (Fig.3). The biggest landslide disaster in the last 10 years in the research area occurred in 2013. The 2013 landslide has closed the total road access in Taji Village, so that for more than 2 weeks the community cannot carry out activities. The Taji Village community realizes that the potential for landslides can increase community togetherness.

The community in the research area, based on the results of the focus group discussion, explained that although the environment was prone to landslides, the community felt comfortable to live in. This is because the community in the research area already has awareness of disasters based on experience. There are several prohibitions that have become the commitment of the community as an effort to reduce the risk of landslides. For example, people are not allowed to cut down trees associated with roads, people are not allowed to carry out intensive cultivation of land near landslides and roads and people are not allowed to cut slopes. The purpose of the ban is to maintain slope stability. If the slope is stable then the potential for soil material movement will be smaller.

The community realizes that in an effort to reduce landslides, it can not only be done by processing the physical environment. The community as one of the elements at risk must also have awareness and knowledge about disasters. Community-based disaster risk reduction is one of the most effective ways.

\section{CONCLUSION}

Taji village, which is located on the southwest flank of Mount Bromo, has a high vulnerability to landslides. The community as an element that has a high risk of landslides has a strategy to reduce the risk of landslides. The community in the research area has awareness, knowledge, preparedness for disasters and for the community the potential for disasters is not a barrier to developing the village. Some of the strategies undertaken by the community to reduce the risk of landslides are optimizing Taji Village as a tourist village, managing the environment with an agroforestry system and empowering the community to reduce the risk of landslides.

\section{REFERENCES}

[1] L. Antronico, F. De Pascale, R. Coscarelli, and G. Gullà, "Landslide risk perception, social vulnerability and community resilience: The case study of Maierato (Calabria, southern Italy)," Int. J. Disaster Risk Reduct., vol. 46, no. February, 2020, doi: 10.1016/j.ijdrr.2020.101529.

[2] D. M. Haskins et al., "A geomorphic classification system," Abstr. with Programs - Geol. Soc. Am., vol. 31, p. 254, 1999.

[3] R. Hoff, "Geology, geomorphology and wine-growing landscape: An approach to regional identity for viticulture at Campanha Wine Region, Brazil," Rev. Bras. Geomorfol., vol. 19, no. 4, pp. 757-776, 2018, doi: 10.20502/rbg.v19i4.1388.

[4] A. B. Murray et al., "Geomorphology, complexity, and the emerging science of the Earth's surface," Geomorphology, vol. 103, no. 3, pp. 496-505, 2009, doi: 10.1016/j.geomorph.2008.08.013.

[5] R. DeFries, "Land use change around protected areas: Management to balance human needs and ecological function," Ecological Applications, vol. 17, no. 4. pp. 1031-1038, 2007, doi: 10.1890/05-1111.

[6] A. Goudie, "The human impact in geomorphology 50 years of change," Geomorphology, vol. 366, p. 106601, 2020, doi: 10.1016/j.geomorph.2018.12.002.

[7] J. Li, L. Yang, R. Pu, and Y. Liu, "A review on anthropogenic geomorphology," J. Geogr. Sci., vol. 27 , no. 1 , pp. $109-128$, 2017, doi: $10.1007 / \mathrm{s} 11442-$ 017-1367-7.

[8] N. Muddarisna, H. Masruroh, and E. D. Yuniwati, "Coping strategy based on socio-agriculture approach in Landslide Prone Area in the Gede Catchment, Malang Regency," pp. 39-43, 2021, doi: 10.1201/9781003178163-9. 
[9] N. Muddarisna, E. D. Yuniwati, H. Masruroh, and A. Rahman, "J OURNAL OF D EGRADED AND M INING L ANDS M ANAGEMENT The effectiveness of cover crops on soil loss control in Gede catchment of Malang Regency, Indonesia," vol. 8, no. 2, pp. 2673-2679, 2021, doi: 10.15243/jdmlm.

[10] J. Franklin, "Multi-attribute vegetation maps of Forest Service lands in California supporting resource management decisions," Photogrammetric Engineering and Remote Sensing, vol. 66, no. 10. pp. 1209-1217, 2000, [Online]. Available: https://www.scopus.com/inward/record.uri?partnerID $=\mathrm{HzOxMe} 3 \mathrm{~b} \& \mathrm{scp}=0033816239$ \&origin $=$ inward .

[11] W. Osterkamp, "The interactions between vegetation and erosion: New directions for research at the interface of ecology and geomorphology," Earth Surface Processes and Landforms, vol. 37, no. 1. pp. 23-36, 2012, doi: 10.1002/esp.2173.

[12] M. P. Bishop, B. W. Young, D. Huo, A. Texas, C. Station, and U. States, "Geomorphometry: Quantitative Land-Surface Analysis and Modeling $i$, , no. July, pp. 1-17, 2018.

[13] J. C. Otto, G. Prasicek, J. Blöthe, and L. Schrott, "GIS Applications in Geomorphology," Compr. Geogr. Inf. Syst., vol. 3, no. 2000, pp. 81-111, 2017, doi: 10.1016/B978-0-12-409548-9.10029-6.

[14] a Weiss, "Topographic position and landforms analysis," Poster Present. ESRI User Conf. San Diego, $C A$, vol. 64, pp. 227-245, 2001, [Online]. Available: http://scholar.google.com/scholar?hl=en\&btnG=Searc $\mathrm{h} \& \mathrm{q}=$ intitle:Topographic+Position+and+Landforms+ Analysis\#0.

[15] Y. F. Liu, Y. Liu, Z. H. Shi, M. López-Vicente, and G. L. Wu, "Effectiveness of re-vegetated forest and grassland on soil erosion control in the semi-arid Loess Plateau," Catena, vol. 195, no. 26, p. 104787 , 2020, doi: 10.1016/j.catena.2020.104787.

[16] C. E. Ramos-Scharrón and Y. Figueroa-Sánchez, "Plot-, farm-, and watershed-scale effects of coffee cultivation in runoff and sediment production in western Puerto Rico," J. Environ. Manage., vol. 202, pp. 126-136, 2017, doi: 10.1016/j.jenvman.2017.07.020.

[17] M. Meliho et al., "Assessment of soil erosion rates in a Mediterranean cultivated and uncultivated soils using fallout 137Cs," J. Environ. Radioact., vol. 208-209, no. January, p. 106021, 2019, doi: 10.1016/j.jenvrad.2019.106021.

[18] J. C. Gill and B. D. Malamud, "Anthropogenic processes, natural hazards, and interactions in a multihazard framework," Earth-Science Rev., vol. 166, pp. 246-269, 2017, doi: 10.1016/j.earscirev.2017.01.002. 